\title{
CIRÚRGIA PARA-ENDODÔNTICA COM RETRO-OBTURAÇÃO: RELATO DE UM CASO CLÍNICO
}

Júlia Lima MORITZ, Sérgio Herrero MORAES, Maria Isabel Anastacio FARIA

O objetivo deste trabalho é relatar um caso clínico de cirurgia periapical com retro-obturação usando o MTA. Paciente do sexo feminino compareceu ao atendimento odontológico com queixa de dor na região do dente 22. Após exame clínico observou-se que outro dentista já havia realizado a abertura coronária, e que o dente encontrava-se aberto ao meio bucal. Após o exame radiográfico foi possível observar obstrução no canal radicular e lesão periapical extensa. Foi realizado na primeira consulta uma tentativa de ultrapassar a calcificação com uma lima modificada, porém sem sucesso. Foi colocada medicação intra-canal $\left(\mathrm{Ca}(\mathrm{OH})_{2}\right)$ por 14 dias. Na segunda consulta 0 dente foi obturado até a medida da calcificação. A cirurgia periapical foi realizada com corte de $2 \mathrm{~mm}$ da porção apical, uso do ultra-som para preparo da cavidade de retro-obturação, que foi preenchida com MTA. A sutura foi retirada 7 dias depois da cirurgia e a proservação foi realizada após 2 meses desta data. A paciente relatou não ter sentido mais dor nesta região. Concluiuse, que quando há a presença de calcificação no interior do canal radicular de dentes portadores de periapicopatias a cirurgia é o meio viável para o tratamento destes casos.

Palavras chaves: endodontia; obturação retrógrada; ultra-som. 